\title{
MANAJEMEN KURIKULUM BERBASIS PENDIDIKAN KARAKTER PADA SEKOLAH DASAR NEGERI UJUNG MENTENG 01 PAGI JAKARTA
}

\author{
Mohamad Arief ${ }^{1}$ dan Rusman ${ }^{2}$ \\ ${ }^{1}$ LPMP DKI Jakarta-Kemdikbud dan ${ }^{2}$ Universitas Pendidikan Indonesia \\ e-mail: mohamad.arief@kemdikbud.go.id
}

\begin{abstract}
Abstrak
Degradasi moralitas kehidupan berbangsa dan bernegara pada kalangan anak-anak remaja (peserta didik) berada pada kondisi yang cukup memprihatinkan. Tergambarkan dari begitu banyaknya permasalahan anak-anak remaja saat ini, yang tergambar baik secara langsung maupun dari berbagai media. Dari latar belakang tersebut, penelitian ini bertujuan untuk menggali, menganalisis dan mendeskripsikan bagaimana manajemen kurikulum berbasis pendidikan karakter diimplementasikan di sekolah. Metode penelitian menggunakan deskriptif dengan pendekatan kualitatif studi kasus. Teknik pengumpulan data dilakukan melalui wawancara, observasi, dan studi dokumentasi. Selain itu peneliti juga bertindak langsung sebagai key instrument untuk mendapatkan data yang jauh lebih mendalam dan bermakna saat di lapangan dari berbagai sumber yang relevan. Hasil penelitian menunjukkan bahwa fungsi-fungsi dari manajemen kurikulum berperan besar dalam keberhasilan sekolah mencapai visi, misi, tujuan, dan program-program sekolah yang dicanangkan. Salah satu faktor penunjang manajemen kurikulum tersebut adalah sikap dan gaya kepemimpinan kepala sekolah. Sebagai ujung tombak dalam manajemen kurikulum, kepala sekolah mengambil peran yang luar biasa sebagai inspirator, motivator, figur keteladanan, supervisi akademik, dan manajerial bagi segenap elemen yang ada di sekolah.
\end{abstract}

Kata Kunci: manajemen kurikulum, pendidikan karakter

\section{CHARACTER BUILDING BASED CURRICULUM MANAGEMENT AT SEKOLAH DASAR NEGERI UJUNG MENTENG 01 PAGI JAKARTA}

\begin{abstract}
The degradation of the morality of nation and state life among children (learners) is in a fairly apprehensive condition. It has been described by so many problems among children, either directly or from various media. From this background, this research aims to analyze, explore and describe how character-based curriculum management is implemented in schools. The research method used is descriptive with qualitative approach of case study. Data collection techniques were conducted through interviews, observations, and documentation studies. In addition, researcher also acts directly as a key instrument when in the field to obtain data which is much more profound and meaningful from various relevant sources. The results show that the functions of curriculum management play major roles in the success of the school to achieve the vision, mission, goals and programs of the school that proclaimed. One of the factors supporting the management of the curriculum is the attitude and style of leadership of the principal. As a spearhead in curriculum management, the principal takes extraordinary roles either as an inspirator, a motivator, an exemplary figure, an academic supervisor, or manager for all elements of the school.
\end{abstract}

Keywords: curriculum management, character building

\section{PENDAHULUAN}

Pendidikan yang bermutu serta berkualitas, merupakan sebuah kebutuhan yang mendasar bagi kehidupan dan peradaban umat manusia. Pendidikan menjadi alat investasi yang sangat berharga 
dalam menentukan serta meningkatkan nilai kehidupan seseorang di masa yang akan datang. Hal senada disampaikan Mulyasa (2003:18), yang mengatakan "Pendidikan merupakan sarana untuk menyiapkan generasi masa kini dan sekaligus masa depan."

Untuk itu dunia pendidikan yang ada senantiasa beradaptasi dan berevolusi, terlebih dalam zaman globalisasi yang berkembang sangat cepat, menjadikan pendidikan sebagai tumpuan dalam melahirkan insan-insan manusia yang berkualitas. Baik dari segi akademik, sikap mental spiritual, serta keterampilan yang memadai. Dunia pendidikan yang ada diharapkan dapat melahirkan insan-insan manusia terdidik yang kaffah, seperti yang tertuang dalam Undang Undang Nomor 20 Pasal 3 Tahun 2003 tentang Sistem Pendidikan Nasional sebagai berikut.

Pendidikan nasional berfungsi mengembangkan kemampuan dan membentuk watak serta peradaban bangsa yang bermartabat dalam rangka mencerdaskan kehidupan bangsa, bertujuan untuk berkembangnya potensi peserta didik agar menjadi manusia yang beriman dan bertakwa kepada Tuhan Yang Maha Esa, berakhlak mulia, sehat, berilmu, cakap, kreatif, mandiri, dan menjadi warga negara yang demokratis serta bertanggung jawab.

Dari pernyataan di atas jelas, bahwa pembangunan nasional Indonesia ditujukan bukan hanya pada pembangunan kecerdasan akademik semata, tetapi juga diarahkan pada bagaimana pendidikan yang syarat akan nilai-nilai menjadi satukesatuan yang utuh pada diri peserta didik. Pendidikan akan karakter ini, diharapkan mampu mengubah perilaku kehidupan, cara berpikir, dan cara bertindak menjadi lebih baik dan berintegritas, khususnya bagi generasi muda. Baik di saat ini maupun di masa yang akan datang.

Program dan kebijakan akan pendidikan karakter telah menjadi pergerakan nasional, yang dilakukan selama bertahuntahun. Akan tetapi, dampak hasil pendidikan karakter yang ada dirasakan belum sepenuhnya tertanam pada jiwa peserta didik. Begitu banyak permasalahan, kendala, dan hambatan yang masih di temukan dalam realitasnya.

Krisis moral multidimensi yang terjadi hampir di seluruh lapisan masyarakat belakangan ini, menunjukkan bahwa identitas bangsa kita sedang terkoyak (Kosim, 2011). Mereka yang diharapkan kelak menjadi generasi kebanggaan dan harapan bangsa, justru telah terlibat dengan berbagai permasalahan. Seperti tindak kekerasan, perkelahian pelajar, video porno, pelecehan seksual, pergaulan bebas, narkoba dan tindakan kriminal lainnya. Ditambah pula dengan semakin maraknya berbagai macam gerakan-gerakan separatis dan kelompok radikal yang mengancam nilai-nilai luhur budaya bangsa serta sikap nasionalisme dalam kehidupan berbangsa dan bernegara.

Berbagai kasus akan lemahnya moralitas kehidupan, khususnya pada anakanak/remaja sering kita saksikan baik secara langsung, maupun dari berbagai media. Seperti beberapa contoh yang tergambarkan tabel 1.

Tabel 1. Tindak kekerasan yang dilakukan anak-anak/remaja

\begin{tabular}{|c|c|c|c|c|}
\hline \multirow[b]{2}{*}{ No } & \multirow[b]{2}{*}{ Kasus } & \multicolumn{3}{|c|}{ Tahun } \\
\hline & & 2014 & 2015 & $\begin{array}{c}\text { s.d. Juli } \\
2016\end{array}$ \\
\hline 1. & $\begin{array}{l}\text { Anak pelaku } \\
\text { tawuran pelajar }\end{array}$ & 46 & 126 & 41 \\
\hline 2. & $\begin{array}{l}\text { Anak korban } \\
\text { kekerasan di } \\
\text { sekolah (bulliying) }\end{array}$ & 159 & 154 & 81 \\
\hline 3. & $\begin{array}{l}\text { Anak pelaku } \\
\text { kekerasan di } \\
\text { sekolah (bulliying) }\end{array}$ & 67 & 93 & 93 \\
\hline 4. & $\begin{array}{l}\text { Anak sebagai } \\
\text { pelaku kekeran fisik } \\
\text { (penganiayaan, } \\
\text { pengeroyokan, } \\
\text { perkelahian, dsb) }\end{array}$ & 105 & 81 & 62 \\
\hline 5. & $\begin{array}{lr}\text { Anak } & \text { sebagai } \\
\text { pelaku } & \text { kekerasan } \\
\text { psikis } & \text { (ancaman, } \\
\text { intimidasi, dsb) }\end{array}$ & 27 & 22 & 23 \\
\hline
\end{tabular}




\begin{tabular}{|c|c|c|c|c|}
\hline \multirow[b]{2}{*}{ No } & \multirow[b]{2}{*}{ Kasus } & \multicolumn{3}{|c|}{ Tahun } \\
\hline & & 2014 & 2015 & $\begin{array}{c}\text { s.d. Juli } \\
2016\end{array}$ \\
\hline 6. & $\begin{array}{l}\text { Anak sebagai } \\
\text { pelaku kepemilikan } \\
\text { senjata tajam }\end{array}$ & 46 & 48 & 14 \\
\hline 7. & $\begin{array}{lr}\text { Anak sebagai } \\
\text { pelaku pembunuhan }\end{array}$ & 66 & 36 & 31 \\
\hline
\end{tabular}

Sumber diolah dari: Komisi Perlindungan Anak Indonesia (KPAI), 2016

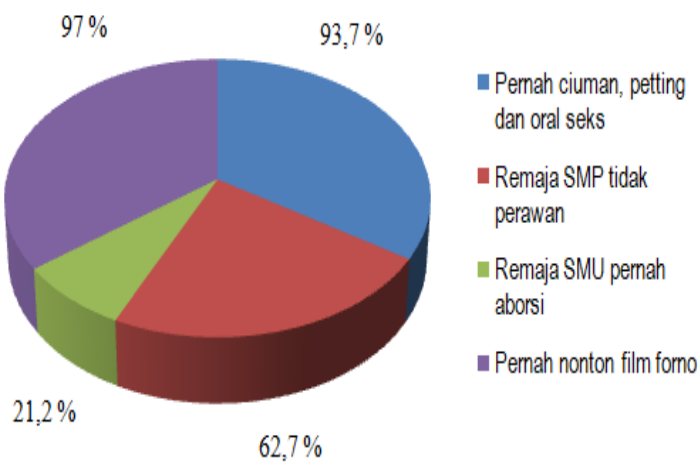

Tabel 1 menunjukkan bahwa tingkat kenakalan anak-anak/remaja dalam kasus kekerasan yang dilakukan masih menjadi salah satu fenomena dan keprihatinan tersendiri. Hasanah (2016) menyajikan data yang bersumber dari Pusat Pengendalian Gangguan Sosial DKI Jakarta, di mana pelajar di provinsi DKI Jakarta yang terlibat tawuran mencapai $0,8 \%$ atau sekitar 1.318 dari 1.645.835 peserta didik yang terdaftar.

Kondisi lebih memprihatinkan adalah, bahwa tindakan kekerasan yang terjadi bukan hanya dilakukan oleh mereka yang berada di jenjang sekolah menengah (SMP, SMA/SMK) saja, namun telah menjalar pada peserta didik yang masih berada di jenjang pendidikan dasar (SD).

Dampak yang dirasakan dari hal tersebut begitu besar, bukan hanya sekedar luka fisik atau trauma. Tetapi tidak sedikit dari mereka yang harus meregang nyawa karena tindakan kekerasan/tawuran yang terjadi. Masa indah sebagai anak-anak/ remaja harus hilang begitu saja karena kelalaian dan perbuatan yang mereka lakukan.

Di sisi lain, kondisi yang lebih memprihatinkan juga terjadi terhadap bagaimana perilaku seksual anakanak/remaja yang ada saat ini. Indonesia, yang dahulu dikenal dengan masyarakatnya yang begitu santun dan menjaga normanorma kesusilaan. Seperti telah terdorong dalam jurang kehancuran moral yang begitu memprihatinkan.

\section{Gambar 1. Perilaku Seksual Pelajar SMP dan SMA/SMK}

Mentoring Agama Islam Weblog (2014) menyajikan, dari data yang telah diteliti oleh Komisi Nasional Perlindungan Anak terhadap 4500 remaja di 12 kota besar di Indonesia pada tahun 2007, diperoleh data pelajar SMP dan SMA yang pernah ciuman, petting, dan oral seks sebanyak 93,70\%. Pelajar SMP yang sudah tidak perawan sebanyak $62,70 \%$. Pelajar SMA yang pernah melakukan aborsi 21,20\%. Serta pelajar yang pernah menonton film porno 97\%. Data-data tersebut telah menggambarkan bagaimana perilaku seks bebas telah melanda kalangan peserta didik dengan membabi buta.

Di sisi lain nilai-nilai etika kesopanan dalam kehidupan sehari-hari peserta didik/anak-anak remaja juga menjadi keprihatinan tersendiri saat ini. Tingkah laku sebagian besar peserta didik/anak-anak remaja saat ini, kian hari berubah secara ironis. Budaya timur akan kesopanan dan keramahan yang dahulu sangat identik dengan bangsa Indonesia, sepertinya telah tergerus oleh berjalannya waktu. Saat ini, sering kali ditemukan baik dalam pergaulan keseharian, maupun dalam postingan di media sosial, mereka mengeluarkan tutur kata, cara berpakaian, dan tingkah laku yang sangat tidak sesuai dengan normanorma yang ada. Lebih memprihatinkan bahwa hal tersebut dianggap sebagai suatu hal yang biasa bahkan trend dikalangan mereka.

Disadari, masih begitu banyak fenomena kenakalan remaja yang terjadi saat ini. Contoh-contoh tersebut sangat erat 
kaitannya dengan pendidikan karakter dan pengelolaan sumber daya manusia, yang menunjukan masih begitu rendah dan rapuhnya fondasi mental spiritual kehidupan bangsa, khususnya di kalangan anakanak/remaja.

Penyimpangan perilaku dan kenakalan tersebut seperti telah melemparkan moralitas sebagian anak-anak/remaja bangsa kita pada titik terendah, "Yang mengesankan bahwa manusia Indonesia hidup dengan hukum rimba pada hutan belantara kota" (Mulyasa, 2013:14).

Terkait hal tersebut, lembaga pendidikan menjadi salah satu sarana yang strategis, khususnya didalam pembentukan karakter. Lembaga pendidikan sebagai sarana pendidikan formal, memiliki beberapa nilai lebih, seperti struktur, sistem, perangkat dan juga sumber daya manusia yang tersebar di seluruh pelosok nusantara.

Namun apakah struktur, sistem, perangkat dan juga sumber daya manusia yang terdapat pada lembaga pendidikan telah di kelola secara optimal dengan seksama? khususnya dalam implementasi kurikulum yang memegang peranan penting dalam sistem pendidikan.

Sebagai salah satu komponen yang memiliki peran vital dan strategis dalam kerangka sistem pendidikan nasional, kurikulum diharapkan mampu mewujudkan tujuan dan cita-cita pendidikan nasional secara menyeluruh (Hamalik, 2010). Hal senada juga di sampaikan oleh Sanjaya (2008) yang menyatakan bahwa kurikulum merupakan suatu komponen yang sangat penting, karena didalamnya menyangkut tujuan, arah pendidikan, pengalaman belajar yang harus dimiliki setiap peserta didik, serta bagaimana mengorganisasi pengalaman itu sendiri.

Kurikulum sebagai sebuah sistem, sangat dipengaruhi oleh berbagai aspek dan komponen. Salah satu aspek yang mempengaruhi keberhasilan kurikulum diantaranya adalah, pemberdayaan dalam bidang manajemen atau pengelolaan kurikulum pada suatu lembaga pendidikan. Proses dan mekanisme dalam berbagai bidang dan aspek kehidupan, khususnya dalam bidang pendidikan tentu sangat diarahkan ke dalam hasil yang efektif dan efisien, serta sesuai dengan tujuan yang diharapkan. Karena itulah, ilmu manajemen memegang peranan yang sangat penting dalam dunia pendidikan khususnya didalam manajemen kurikulum.

Defyanti (2014) menyatakan, ada tiga aspek yang sangat penting dan hal tersebut merupakan ruhnya pada setiap kurikulum, yaitu: 1) materi pembelajaran, 2) peran guru dan juga peran kepala sekola, serta 3) manajemen kurikulum yang dilaksanakan sekolah. Manajemen kurikulum merupakan salah satu substansi yang utama di sekolah. Secara garis besar, prinsip dasar manajemen kurikulum ini adalah berusaha agar proses pembelajaran dapat berjalan dengan baik, dengan tolak ukur pencapaian tujuan oleh peserta didik, serta mendorong guru untuk menyusun dan secara terus menerus menyempurnakan strategi di dalam pembelajaran.

Berdasarkan berbagai fenomena yang telah dijelaskan tersebut, Penulis memiliki ketertarikan untuk meneliti lebih mendalam terkait pendidikan karakter dari segi ilmu manajemen terhadap kurikulum yang diimplementasikan. Ilmu manajemen tidak hanya dipahami sebagai disiplin ilmu, tetapi juga sangat penting implementasinya didalam kehidupan sehari-hari terlebih dalam dunia pendidikan. Manajemen memegang peranan penting sebagai ujung tombak keberhasilan pengelolaan kurikulum di satuan pendidikan, mulai dari perencanaan kurikulum, implementasi kurikulum, hingga evaluasi kurikulum.

Hamalik (2010:16) menyatakan "Manajemen merupakan proses sosial yang berkaitan dengan keseluruhan usaha manusia dengan bantuan manusia lain, serta sumber-sumber lainnya, menggunakan metode yang efisien dan efektif untuk mencapai tujuan yang ditentukan sebelumnya."

Berbagai permasalahan yang timbul dalam dunia pendidikan adakalanya sering di latar belakangi karena tidak mampunya seseorang mengatur ilmu manajemen. 
Seperti yang disampaikan oleh Hasan (Wahyudin, 2014) jika prinsip manajemen tidak dilaksanakan dengan baik dalam pendidikan, maka kurikulum dalam bentuk dokumen yang telah tersedia akan menjadi inertia. Dalam hal ini diartikan kurikulum yang ada menjadi bisu dan dibalut oleh ketidakjelasan.

Manajemen kurikulum yang diimplementasikan pada satuan pendidikan diharapkan dapat memberikan penekanan akan terbukanya ruang baru yang memiliki nilai terhadap seluruh stakeholder pendidikan, dan memberikan kontribusi nilai lebih secara berkelanjutan terhadap apa yang diperlukan oleh lembaga pendidikan dan peserta didik di masa mendatang, seperti yang di sampaikan oleh Ahmadi (2013).

Dari beberapa rumusan tentang konsep dan definisi, maka terdapat beberapa poin penting terkait manajemen, seperti yang diungkapkan Hamalik (Wahyudin, 2014:18), di antaranya adalah: 1) Manajemen adalah suatu proses sosial yang merupakan proses kerjasama antara dua orang atau lebih secara formal; 2) Manajemen dilaksanakan dengan bantuan sumber-sumber, yakni sumber manusia, sumber material, sumber biaya, dan sumber informasi; 3) Manajemen dilaksanakan dengan metode kerja tertentu yang efisien dan efektif, dari segi tenaga, dana, waktu, dan sebaginya; dan 4) Manajemen mengacu pada pencapaian tujuan tertentu yang telah ditentukan sebelumnya.

Fungsi-fungsi atau prinsip-prinsip yang terdapat dalam manajemen kurikulum pada umumnya sama halnya dengan fungsi manajemen secara umum yang ada. Beberapa diantaranya disampaikan oleh Wahyudin (2014) dan Hamalik (2010), dimana dalam konteks kurikulum untuk tingkat satuan pendidikan, siklus manajemen kurikulum terdiri dari empat fungsi, yaitu: perencanaan, pengembangan, implementasi dan pelaksanaan, serta penilaian. Sedangkan Rusman (2011) dan Stoner (Ahmadi, 2013) manajemen kurikulum meliputi perencanaan, pengorganisasian, pelaksanaan dan evaluasi kurikulum.
Namun didalam penelitian ini pembahasan akan dibatasi dari tiga fungsi saja, yaitu perencanaan (planning), Pelaksanaan (implementation), dan evaluasi (evaluation).

Pertama, perencanaan. Merupakan sebuah fungsi manajemen yang ditujukan dalam mengembangkan suatu rencana senantiasa mengacu dan berorientasi ke depan. Perencanaan kurikulum didukung dengan berbagai langkah, diantaranya: menetapkan perangkat tujuan atau hasil akhir seperti visi dan misi serta tujuan organisasi, menetapkan strategi untuk mencapai tujuan akhir, menyusun programprogram prioritas, menetapkan prosedur kerja, dan mengembangkan kebijakankebijakan berupa aturan dan ketentuan.

Sementara itu Ahmadi (2013) menyatakan beberapa hal yang perlu diperhatikan dalam perencanaan kurikulum adalah menganalisis isu-isu eksternal terkait dengan perkembangan dan kebutuhan yang ada di masyarakat, merumuskan tujuan satuan pendidikan, menganalisis kekuatan internal yang dimiliki, menyusun tim perumus kurikulum, dan alokasi waktu dalam perumusan perencanaan kurikulum.

Kedua, implementasi kurikulum. implementasi kurikulum merupakan bentuk aktualisasi dari kurikulum yang telah direncanakan. Implementasi kurikulum di lapangan menjadi salah satu faktor utama yang menentukan terhadap keberhasilan ataupun kegagalan kurikulum. Untuk itu, keserasian dan keselarasan antara perencanaan kurikulum dan implementasi atau pelaksanaan kurikulum senantiasa di kendalikan secara seksama, sehingga ketercapaian tujuan dan sasaran yang telah ditetapkan dapat diwujudkan.

Oliva (1992:26) "Curriculum implementation means putting the curriculum to work." Secara konsep dan makna Implementasi merupakan suatu proses penerapan ide, konsep, kebijakan, atau inovasi dalam suatu tindakan praktis.

Dalam pelaksanaan kurikulum peran daripada guru dan juga kepala sekolah menjadi sorotan utama. Karena merekalah 
pelaksana dan ujung tombak pelaksanaan kurikulum yang ada. Dapat dikatakan sebaik apapun kurikulum yang dimiliki, tanpa didukung oleh kompetensi guru dan kepala sekolah yang memadai, maka hal itu bisa berakibat kurang optimal.

Ketiga, evaluasi dan pengendalian kurikulum. Merupakan fungsi yang ditujukan untuk memastikan semua fungsi lainnya dapat berjalan dengan sebagaimana mestinya. Fungsi pengendalian ini biasanya sangat erat kaitannya dengan fungsi evaluasi yang ada.

Evaluasi menurut Tyler (1949) adalah "The process for determining the degree to which these change in behavior are actually taking place...". Menurut beliau evaluasi berfokus terhadap sebuah upaya dalam rangka menentukan tingkat perubahan yang terjadi terhadap hasil belajar pada peserta didik. Evaluasi terhadap tingkat perubahan yang terjadi dilakukan baik secara statistik, maupun secara edukatif.

Fungsi ini biasanya terdiri dari langkah-langkah pengendalian terhadap usaha yang dilakukan, membangun sistem pelaporan yang akuntabel, mengukur hasil pencapaian yang telah ditentukan, serta melakukan tindakan koreksi dan perbaikan yang di perlukan.

Hasan (Ahmadi, 2013) menegaskan evaluasi kurikulum dimaksudkan untuk keperluan: i) perbaikan program, ii) pertanggungjawaban kepada berbagai pihak, iii) penentuan tindak lanjut. Sehingga dapat dikatakan bahwa evaluasi sangat erat kaitannya dalam memberikan informasi dalam pengambilan keputusan

\section{METODE}

Metode yang digunakan dalam penelitian ini adalah metode penelitian studi kasus dengan pendekatan deskriptif kualitatif. Teknik pengumpulan data yang dilakukan melalui observasi, wawancara, dan juga studi dokumentasi yang merupakan metode dalam pendekatan penelitian kualitatif (Ali, 2014 ; Creswell, 2017).

Selain itu juga peneliti bertindak langsung sebagai key instrument. Pemilihan metode studi kasus ini didasarkan terhadap fokus penelitian dalam mengamati dan menganalisis suatu gejala yang terjadi secara alamiah.

Beberapa kelebihan metode studi kasus yang disampaikan Miles dan Huberman (Ali, 2014:440) "Data kualitatif bersifat membumi, kaya akan deskripsi dan mampu menjelaskan tentang proses." Sehingga dengan metode studi kasus ini diharapkan mendapatkan gambaran yang komprehensif terkait implementasi manajemen kurikulum pendidikan karakter yang ada.

Prosedur penelitian disini dikaitkan terhadap tahapan-tahapan yang dilakukan dalam penelitian. Tahapan penelitian yang dilakukan oleh mengacu pada Creswell (2017).

Tahap kesatu, persiapan penelitian. Terdiri dari kegiatan identifikasi masalah dan mencari fokus masalah, melakukan dan mengkaji studi pustaka, menentukan metodologi dan menyusun instrumen penelitian (pedoman wawancara, pedoman observasi) serta menentukan sampel penelitian.

Tahap kedua, pelaksanaan penelitian. Pada tahap ini terdiri dari kegiatan utama, yaitu: i) pengumpulan data terdiri dari kegiatan observasi, wawancara dan studi dokumentasi; ii) pengolahan/analisis data terdiri dari kegiatan reduksi data, displai data, kesimpulan dan verifikasi.

Tahap ketiga, laporan hasil penelitian.

\section{HASIL DAN PEMBAHASAN}

SDN Ujung Menteng 01 Pagi Jakarta, merupakan sekolah yang berada di timur Jakarta, dan berbatasan langsung dengan kota administratif Bekasi, Jawa Barat. Sekolah yang didirikan pada tahun 1979 ini, merupakan sekolah piloting project dalam program Penguatan Pendidikan Karakter (PPK), yang dicanangkan pemerintah. Selain itu, SDN Ujung Menteng 01 Pagi Jakarta senantiasa menanamkan pendidikan akan nilai-nilai didalam aktivitas pembelajaran dan kegiatan disekolah, serta menjadikan sekolah ini sebagai 'Sekolah Ramah Anak'. 
Sepanjang kiprah perjalanannya, SDN Ujung Menteng 01 Pagi Jakarta senantiasa diwarnai dengan berbagai prestasi. Baik prestasi dalam bidang akademik maupun non-akademik. Prestasi yang diraihpun sangat variatif dan di berbagai jenjang level. Mulai dari tingkat kecamatan, kota madya, provinsi, hingga tingkat nasional. Beberapa prestasi yang menjadi daya tarik tersendiri bagi Peneliti adalah diraihnya juara I dan III tingkat nasional pada lomba budaya mutu tahun 2017 dan 2016, untuk kategori ekstrakurikuler dan MBS.

Dalam buku panduan lomba budaya mutu (LPMP DKI Jakarta, 2017) dikatakan, budaya mutu sekolah merupakan program yang diimplementasikan di sekolah dalam rangka membudayakan tata kelola sekolah yang baik serta membentuk peserta didik menjadi manusia yang beriman, berakhlak mulia, jujur, optimis, berani, terampil, berperilaku kooperatif, ulet, disiplin, beretos kerja yang tinggi, dan pandai menangkap peluang. Maka dapat dikatakan prinsip-prinsip yang terdapat dalam budaya mutu sekolah ini sangat relevan terhadap pembahasan manajemen kurikulum pada pendidikan karakter.

Manajemen kurikulum yang dilakukan merupakan komitmen seluruh warga sekolah SDN Ujung Menteng 01 Pagi Jakarta. Hal tersebut ditujukan untuk menunjang segala aktifitas persekolahan, khususnya di dalam pembelajaran. Serta mewujudkan visi, misi, dan tujuan yang telah ditetapkan. Fungsi-fungsi manajemen kurikulum berbasis pendidikan karakter yang dibahas pada jurnal ini dibatasi terhadap tiga fungsi, yaitu: i) manajemen perencanaan kurikulum; ii) manajemen pelaksanaan (implementasi) kurikulum; dan iii) manajemen evaluasi/pengendalian kurikulum.

\section{Hasil}

Manajemen Kurikulum pada SDN Ujung Menteng 01 Pagi Jakarta, dilakukan dengan sebaik mungkin sebagai bentuk apresiasi dan tanggungjawab sekolah mewujudkan dan mencapai cita-cita pendi- dikan nasional, yakni mencerdaskan kehidupan bangsa.

Manajemen kurikulum yang dilaksanakan ditunjang oleh berbagai faktor, diantaranya yaitu kecakapan kepemimpinan yang dilakukan oleh Kepala Sekolah, SDM pelaksana kurikulum (guru dan tenaga kependidikan) yang memiliki kompetensi dan sikap profesionalisme yang sangat baik, dan juga peran serta komite sekolah yang sangat kooperatif. Apabila dari beberapa unsur tersebut salah satunya melemah, maka tentu saja akan sangat mempengaruhi keselarasan antar tahapan manajemen kurikulum yang dilakukan.

Manajemen perencanaan kurikulum yang ada di SDN Ujung Menteng 01 Pagi Jakarta, dijalankan melalui beberapa tahapan, yaitu: 1) pembentukan tim inti kurikulum; 2) analisis kondisi internal dan eksternal sekolah; 3) perumusan visi sekolah; 4) menetapkan misi sekolah; dan 5) menetapkan tujuan sekolah.

Sementara itu, perencanaan kurikulum berbasis pendidikan karakter di SDN Ujung Menteng 01 Pagi Jakarta terkristalisasi dalam lima nilai utama, yaitu: religius, integritas, nasionalisme, gotongroyong dan mandiri. Dimana nilai-nilai tersebut senantiasa diintegrasikan dalam seluruh kegiatan dan pembelajaran yang ada di lingkungan sekolah SDN Ujung Menteng 01 Pagi Jakarta.

Manajemen pelaksanaan (implementasi) kurikulum SDN Ujung Menteng 01 Pagi Jakarta terdiri dari beberapa langkah utama, yaitu: 1) senantiasa mengembangkan visi, misi dan tujuan sekolah sesuai dengan perkembangan konteks pendidikan dasar; 2) mengkonstruk struktur kurikulum SDN Ujung Menteng 01 Pagi Jakarta; 3) pelaksanaan pembelajaran dengan pendekatan tematik terpadu; 4) pengembangan evaluasi hasil belajar; dan 5) internalisasi nilai-nilai karakter, yaitu nilai religius, integritas, nasionalisme, gotong royong, mandiri dan sebagainya.

Nilai lebih tersendiri yang dilakukan SDN Ujung Menteng 01 Pagi Jakarta adalah bahwa setiap aktifitas kegiatan dan pembelajaran yang ada di lingkungan 
sekolah memiliki Standar Operational Procedure (SOP).

Manajemen evaluasi/pengendalian kurikulum di SDN Ujung Menteng 01 Pagi Jakarta, terdiri dari beberapa langkah utama yaitu: 1) evaluasi dokumen kurikulum; 2) evaluasi implementasi kurikulum; dan 3) evaluasi hasil belajar.

Untuk mewujudkan implementasi kurikulum yang ajeg dan handal, pengendalian kurikulum senantiasa dilakukan, khususnya oleh kepala sekolah dengan membangun komunikasi dan komitmen bersama dalam melaksanakan tupoksi masing-masing seluruh warga sekolah.

\section{Pembahasan}

\section{Manajemen Perencanaan Kurikulum Berbasis Pendidikan Karakter SDN Ujung Menteng 01 Pagi Jakarta}

Perencanaan kurikulum pada SDN Ujung Menteng 01 Pagi Jakarta, dijadikan sebagai arah pedoman penyelenggaraan aktifitas pembelajaran, untuk mencapai tujuan yang telah ditetapkan. Perencanaan tersebut diorientasikan terhadap pengembangan multi kompetensi (karakter) yang ada pada diri peserta didik. Hal tersebut menjadikan perencanaan kurikulum menjadi titik awal dan kunci penting di dalam implementasi kurikulum yang ada di sekolah.

Dalam wemujudkan perencanaan kurikulum yang ajeg dan handal. Segenap warga sekolah baik guru, tenaga kependidikan, komite sekolah dan khususnya kepala sekolah, senantiasa memperhatikan langkah-langkah penting dan juga faktor-faktor yang berpengaruh di dalamnya secara seksama. Kepala sekolah memegang peranan yang begitu penting, sebagai inisiator, konseptor, motivator, regulator, dan khususnya didalam membangun komunikasi yang ada dengan seluruh warga sekolah. Langkah-langkah dalam perencanaan kurikulum SDN Ujung Menteng 01 Pagi Jakarta adalah sebagai berikut.

Pertama, pembentukan tim inti kurikulum. Kepala sekolah sebagai top manajemen yang ada di sekolah, melakukan langkah-langkah awal di dalam perumusan perencanaan. Kepala sekolah bersama wakilnya membentuk tim inti kurikulum SDN Ujung Menteng 01 Pagi Jakarta yang terdiri dari kepala sekolah, wakil kepala sekolah, dan beberapa orang guru. Tentu saja pemilihan tim inti kurikulum yang dibentuk memiliki dasar pertimbangan, di antaranya memiliki kompetensi dan kapasitas mumpuni di dalam merumuskan dan mewujudkan kurikulum satuan pendidikan yang ada mulai dari perencanaan, pelaksanaan dan evaluasi kurikulum.

Tim inti kurikulum ini memegang peranan yang sangat penting di sekolah. Sehingga pemilihan dan penetapan tim inti kurikulum ini juga senantiasa dikoordinasikan dan dikomunikasikan dengan seluruh guru dan juga komite sekolah. Sehingga kepercayaan, komunikasi, komitmen, dan koordinasi yang ada dapat terjalin dengan baik terhadap seluruh warga sekolah.

Kedua, analisis kondisi internal dan eksternal sekolah. Tim inti kurikulum yang telah dibentuk kemudian melakukan langkah-langkah persuasif guna mewujudkan perencanaan kurikulum yang ada. Analisis yang dilakukan menjadi langkah untuk menentukan kebijakan lebih lanjut. Analisis dilakukan terhadap: 1) Kondisi internal. Meliputi kondisi peserta didik, guru, tenaga kependidikan, sarana prasarana sekolah, pembiayaan, dan juga tata kelola organisasi yang ada; 2) Kondisi eksternal. Output yang diharapkan dari sekolah tentu bukan saja peserta didik yang memiliki kecakapan akademik semata, tetapi juga bagaimana peserta didik dapat mengaktualisasikan apa yang di dapat disekolah kedalam lingkungan masyarakat. Sehingga analisis kondisi eksternal juga menjadi pertimbangan penting. Kondisi eksternal yang di analisis diantaranya adalah: pengaruh terhadap kebutuhan dan tantangan dalam perkembangan IPTEKS dan arus globalisasi, nilai-nilai budaya yang ada dan berkembang di masyarakat, peraturan perundang-undangan yang berlaku terhadap sistem pendidikan, ling- 
kungan geografis, kondisi masyarakat sekitar, serta orang tua/wali murid. Analisis kondisi internal dan eksternal yang dilakukan menjadi bahan masukan dan pertimbangan bagi pihak sekolah dalam merumuskan visi, misi, serta tujuan sekolah.

Ketiga, perumusan visi sekolah. Ahmadi (2013) menyatakan, visi adalah tindakan, kekuatan, kecakapan atau kemampuan melihat dan memahami untuk berimajinasi dalam persiapan masa datang. Dengan demikian, visi senantiasa dijadikan acuan dalam menetapkan arah perkembangan organisasi. Visi yang dirumuskan oleh tim inti kurikulum adalah "Menjadikan SDN Ujung Menteng 01 Pagi Sebagai Sekolah Unggulan Berdasarkan Akhlaqul Karimah dan Berwawasan Lingkungan." Visi yang dirumuskan tersebut merupakan hasil dari analisis yang komprehensif terhadap kondisi internal dan eksternal sekolah dan cita-cita kedepan. Dari visi tersebut dapat tergambarkan bagaimana kebutuhan peserta didik terhadap pendidikan karakter (akhlaqul karimah) menjadi perhatian serius pihak sekolah. Selain itu kebutuhan dalam kehidupan bermasyarakat, berbangsa dan bernegara termasuk lingkungan masyarakat global juga menjadi perhatian sekolah.

Keempat, menetapkan misi sekolah. Misi ini diturunkan dari visi yang sebelumnya telah dirumuskan. Misi ini bersifat lebih operasional. Secara umum misi merupakan alasan keberdaan. Sallis (Ahmadi, 2013:32) "The mission statement is closely linked to the vision, and provides a clear direction for the present and the future." Misi yang terdapat dalam SDN Ujung Menteng 01 Pagi Jakarta terdiri dari: 1) Meningkatkan kegiatan pembiasaan positif untuk membentuk akhlaq mulia; 2) Meningkatkan kegiatan pembelajaran berbasis IT; 3) Meningkatkan kegiatan ekstrakurikuler; 4) Menumbuh kembangkan semangat keunggulan dan cinta tanah air; 5) Menciptakan lingkungan yang asri sebagai salah satu sumber belajar; dan 6) Meningkatkan kerjasama yang harmonis dengan warga sekolah, komite, masyarakat, maupun dunia usaha.

Misi SDN Ujung Menteng 01 Pagi Jakarta ditujukan terhadap orientasi berbasis akhlaqul karimah dan mampu menjawab tantangan jaman dalam perkembangan IPTEKS, serta menjaga nila-nilai budaya yang berwawasan lingkungan. Tentu saja misi yang telah dirumuskan ini diharapkan mampu menjadi bahan referensi terhadap apa yang harus dilakukan.

Kelima, menetapkan tujuan sekolah. Tujuan pada SDN Ujung Menteng 01 Pagi Jakarta adalah: 1) Terbinanya peserta didik yang berkepribadian, berakhlak mulia, berbudaya dan memiliki kepedulian sosial; 2) Terwujudnya peserta didik yang kompetitif, berkualitas dan cinta tanah air; 3) Berkembangnya potensi, bakat dan minat peserta didik; 4) Menumbuhkembangkan rasa cinta kebersihan, keindahan, keamanan, kesehatan dan kekeluargaan; dan 5) Menuntaskan program wajib belajar sembilan tahun. Tujuan sekolah yang ditetapkan berfokuskan terhadap usaha dalam meningkatkan kemampuan peserta didik secara komprehensif baik dari segi kognitif, afektif dan psikomorik. Tujuan tersebut tiada lain untuk merealisasikan visi dan misi yang telah ditetapkan.

Sebelum dilegitimasi dan finalisasi, kepala sekolah bersama tim inti kurikulum mensosialisasikan visi, misi, dan tujuan sekolah yang telah dirumuskan melalui beberapa tahapan. 1) Visi, misi, dan tujuan sekolah dipaparkan dalam rapat dengan seluruh guru yang ada. Hal tersebut ditujukan untuk mendapatkan saran, masukan dan pertimbangan lebih lanjut dari seluruh guru yang ada. Jika terdapat saran dan masukan, maka akan dilakukan beberapa penyesuaian, untuk kemudian dijadikan keputusan bersama seluruh guru dan tenaga kependidikan; 2) Visi, misi, dan tujuan sekolah tersebut juga akan dipaparkan sekolah dihadapan komite sekolah sehingga tersosialisasikan dan terkoordinasikan dengan baik, terhadap seluruh warga sekolah SDN Ujung Menteng 01 Pagi Jakarta. 
Selain itu perencanaan kurikulum yang dilakukan, senantiasa memperhatikan berbagai faktor lainnya yang erat dan relevan untuk dijadikan bahan referensi dan pertimbangan, diantaranya yaitu: 1) sosialisasi perencanaan kurikulum senantiasa dilakukan sehingga dapat terinsternalisasi dan terkristalisasi pada seluruh warga sekolah, diantaranya melalui banner-banner yang berisi visi, misi dan tujuan sekolah yang terpasang hampir diseluruh sudut sekolah; 2) apel pagi yang dilakukan setiap hari untuk senantiasa mengingatkan dan membudayakan dalam mewujudkan visi, misi, dan tujuan sekolah; 3) kurikulum yang direncanakan senantiasa diarahkan dalam mengembangkan keteram-pilan berbasis IT; 4) melakukan rencana kerjasama dengan berbagai pihak terkait, untuk mendukung aktifitas pembelajaran dan kegiatan di SDN Ujung Menteng 01 Pagi Jakarta; 5) membuat draf-draf evaluasi pembelajaran meliputi KKM, kriteria kenaikan kelas, dan kelulusan sekolah.

Dari visi, misi dan tujuan sekolah yang telah ditetapkan, langkah selanjutnya adalah SDN Ujung Menteng 01 Pagi Jakarta, merumuskan program-program kegiatan dan pembelajaran yang kemudian dituangkan dalam dokumen. Yang terdiri dari program makro (renstra), program mikro (rencana kerja tahunan), program mikro pengembangan budaya mutu, dan rencana pengembangan sekolah (pengembangan budaya mutu).

Selanjutnya kepala sekolah melakukan validasi dengan pihak-pihak terkait, yaitu pengawas sekolah dan juga dinas pendidikan untuk disahkan secara formal menjadi kurikulum tingkat satuan pendidikan pada SDN Ujung Menteng 01 Pagi Jakarta.

Dokumen perencanaan kurikulum, yang kemudian disebut dokumen kurikulum tingkat satuan pendidikan merupakan perangkat pembelajaran yang dalamnya terdiri dari kalender pendidikan, pengembangan silabus, KKM, rencana pelaksanaan pembelajaran (KI, KD, materi, strategi pembelajaran, evaluasi pembelajaran, media pembelajaran, dan referensi), serta program-program pengembangan dan kegiatan sekolah.

Sementara itu, perencanaan kurikulum berbasis pendidikan karakter di SDN Ujung Menteng 01 Pagi Jakarta terkristalisasi dalam lima nilai utama, yaitu: religius, integritas, nasionalisme, gotongroyong dan mandiri. Di mana nilai-nilai tersebut senantiasa diintegrasikan dalam seluruh kegiatan dan pembelajaran yang ada di lingkungan sekolah SDN Ujung Menteng 01 Pagi Jakarta.

Religius, rencana pengembangan terhadap nilai religius ini ditujukan dalam rangka mengembangkan keimanan dan ketaqwaan kepada Allah SWT, berakhlaq mulia, taat beribadah, termasuk budi pekerti luhur, kepribadian unggul, sopan, santun dan sebagainya.

Integritas, rencana pengembangan terhadap nilai integritas ini ditujukan untuk menanamkan nilai-nilai kejujuran, kebenaran, tanggungjawab, percaya diri, kendali diri, bahkan juga melahirkan nilai-nilai kepemimpinan.

Nasionalisme, rencana pengembangan terhadap nilai nasionalisme ini ditujukan untuk menumbuhkan sikap cinta tanah air, demokratis, menjunjung tinggi hak asasi manusia, menghargai perbedaan dalam kehidupan bermasyarakat, berbangsa dan bernegara.

Gotong Royong, Tujuan pembelajaran nilai gotong royong ini adalah untuk meningkatkan kecakapan dalam bekerjasama dan kekeluargaan secara harmonis.

Mandiri, Tujuan pembelajaran dari nilai ini untuk mengarahkan peserta didik pada peningkatan kemandirian dan kedewasaan dalam diri mereka.

Beberapa hal yang dilakukan dalam perencanaan kurikulum berbasis penddikan karakter sebagai berikut.

Pertama, sebagai sekolah yang telah melaksanakan program penguatan Pendidikan Karakter (PPK). SDN Ujung Menteng 01 Pagi Jakarta, senantiasa menganalisis kebutuhan akan pendidikan karakter yang diperlukan oleh peserta didik, yaitu cakap secara akademik, sosial, berfikir, religius, dan berakhlaqul karimah 
(seperti yang dituangkan pihak sekolah dalam visi sekolah).

Kedua, pendidikan karakter yang ditekankan senantiasa disesuaikan dengan kebutuhan dan tantangan saat ini, termasuk untuk melahirkan insan peserta didik yang mampu beradaptasi dalam perkembangan IPTEKS dan perubahan sosial masyarakat.

Ketiga, proses analisis pendidikan karakter senantiasa memperhatikan kebutuhan dan perkembangan peserta didik secara utuh dan komprehensif (baik olah hati, olah pikir, olah raga, olah rasa dan karsa).

Keempat, melakukan dan mengimplementasikan kurikulum berbasis pendidikan karakter secara terintegrasi dan terinternalisasi dalam seluruh aktivitas yang ada di sekolah baik dalam kegiatan pembelajaran di dalam kelas, maupun dalam kegiatan pendidikan secara umum yang ada di SDN Ujung Menteng 01 Pagi.

Kelima, mengembangkan diversifikasi ekstrakurikuler berbasis diversifikasi dan preferensi peserta didik.

\section{Manajemen Pelaksanaan Kurikulum Berbasis Pendidikan Karakter SDN Ujung Menteng 01 Pagi Jakarta}

Pelaksanaan (implementasi) kurikulum senantiasa dilaksanakan dengan sebaik mungkin. Karena di sinilah penentu keberhasilan terhadap perencanaan yang telah ditetapkan. Untuk itu, elemen yang berkaitan langsung dalam implementasi kurikulum, dalam hal ini guru senantiasa diarahkan untuk memiliki kompetensi yang mumpuni serta memiliki jiwa inovatif, kreatif, dan kompetitif untuk mewujudkan tujuan yang ada. Selain itu tenaga kependidikan juga tidak dapat dikesampingkan. Perannya dalam implementasi kurikulum juga sangat penting sebagai faktor pendukung, tanpa peran mereka maka implementasi kurikulum yang ada dapat berjalan kurang optimal.

Dalam implementasi kurikulum kepala sekolah memegang peranan mulai dari melakukan pengarahan, memotivasi, menjadi figur teladan, dan juga supervisi akademik, demi terlaksananya implementasi kurikulum, serta mewujudkan mutu yang ada bagi pendidik dan tenaga kependidikan. Untuk mewujudkan hal tersebut ada beberapa langkah strategis yang diambil kepala sekolah.

Pertama, kepala sekolah senantiasa mensosialisasikan serta mensinergikan visi, misi, dan tujuan sekolah secara rutin dan berkesinambungan terhadap seluruh warga sekolah baik guru, tenaga kependidikan, dan juga komite sekolah. Langkah yang dilakukan di antaranya, melakukan pertemuan rutin dengan guru dan tenaga kependidikan baik minguan (setiap hari Rabu pagi, saat peserta didik melakukan aktifitas ekstrakurikuler), bulanan, dan juga semesteran. Dalam pertemuan yang dilakukan biasanya terkait dengan pengembangan program yang harus segera ditindaklanjuti serta mencari solusi jika dalam perjalanannya ditemukan kendala atau hambatan. Selain itu pertemuan juga dilakukan untuk menjelaskan dan menetapkan teknis pelaporan kegiatan yang dilakukan baik oleh pendidik dan tenaga kependidikan.

Kedua, visi, misi, dan tujuan yang telah ditetapkan kemudian diturunkan ke tingkat operasional tugas guru. Yang dilakukan dengan membuat silabus, RPP, program semesteran, program tahunan, termasuk di dalamnya pengembangan materi dan pengalaman yang akan diterima peserta didik. Dalam hal ini guru juga senantiasa melakukan pertemuan dengan dewan kelas yang dilakukan paling tidak sebulan sekali untuk mewujudkan komitmen bersama antara sekolah dengan orang tua/wali murid.

Ketiga, membangun komitmen bersama mewujudkan mutu akademik yang ada di SDN Ujung Menteng 01 Pagi Jakarta. Dengan beberapa langkah diantaranya dengan melaksanakan program budaya mutu sekolah, program Penguatan Pendidikan Karakter, dan sekolah ramah anak. Selain itu, untuk mewujudkan lulusan sekolah yang lebih baik, sekolah melakukan bimbingan super intensif yang dilakukan terhadap siswa kelas VI untuk menghadapi UASBN. 
Keempat, pendidikan dan pelatihan yang ditujukan bagi guru dan tenaga kependidikan. Pelatihan-pelatihan yang diikuti bagi guru diantaranya adalah diklat Kurikulum 2013, diklat pendidikan karakter dan sebagainya. Baik yang dilakukan secara internal maupun dari pihak-pihak terkait. Termasuk pelatihan bagi tenaga kependidikan, dalam mendukung implementasi kurikulum yang ada.

Kelima, melakuan Memorandum of Understanding (MoU) dengan pihak-pihak luar terkait. Hal tersebut ditujukan untuk memberikan pengetahuan, wawasan dan pengalaman pada peserta didik secara lebih matang dalam lingkungan masyarakat.

Keenam, memfasilitasi sarana dan prasarana yang diperlukan sekolah. Seperti membangun ruang belajar sesuai dengan rombel, perpustakaan, laboratorium, panggung kreasi, masjid, taman hati, taman baca, kantin, UKS, dan sebagainya. Selain itu sekolah juga menyediakan fasilitas CCTV sebagai alat monitoring kegiatan pembelajaran di kelas. Sementara itu untuk pengendalian dan pengawasan terhadap guru dan tenaga kependidikan sekolah juga memfasilitasi presensi berbasis eletronik.

Dengan memanfaatkan input diatas, implementasi kurikulum dilaksanakan dengan beberapa tahapan.

Pertama, senantiasa mengembangkan visi, misi, dan tujuan sekolah sesuai dengan perkembangan konteks pendidikan dasar. Seperti dijelaskan di awal bahwa visi, misi, dan tujuan merupakan ruh dari sekolah. Maka dalam setiap kegiatan senantiasa melakukan pendekatan dan pengembangan terhadap visi, misi, dan tujuan yang telah ditetapkan.

Kedua, mengkonstruk struktur kurikulum SDN Ujung Menteng 01 Pagi Jakarta. Langkah-langkah yang dilakukan di antaranya: i) senantiasa mempelajari, mengembangkan dan mengimplementasikan struktur kurikulum sesuai kaidah yang terdapat dalam Kurikulum 2013; ii) mengembangkan dan mengfinalisasi beban belajar masing-masing struktur kurikulum pada masing-masing kelas; iii) mengembangkan aneka ragam pengembangan diri peserta didik sesuai dengan minat dan bakat; iv) senantiasa mengkristalisasi nilainilai pendidikan karakter baik melalui integrasi dalam pembelajaran tematik terpadu, maupun pembelajaran dalam melalui budaya/pembiasaan-pembiasaan dalam keseharian.

Ketiga, pelaksanaan pembelajaran dengan pendekatan tematik terpadu, melalui beberapa tahapan: i) memberi tugas kepada guru sesuai dengan hasil penilaian yang dilakukan kepala sekolah, dengan pendekatan persuasif; ii) menyarankan guru untuk memperhatikan kompetensi inti dan kompetensi dasar, iii) guru secara bersamasama menetapkam kriteria kelulusan minimal (KKM), iv) guru mengembangkan silabus, mencakup materi, skenario pembelajaran, evaluasi dan sumber/media, v) guru membuat RPP masing-masing, vi) guru dan siswa melakukan pembelajaran berbasis peserta didik, IT, dan akhlaqul karimah, vii) guru membangun komunikasi dengan dewan kelas, dan komite, viii) guru dan siswa membangun komunikasi yang efektif.

Untuk pembelajaran muatan lokal Pendidikan Lingkungan dan Budaya Jakarta (PLBJ) pelaksanaannya diintegrasikan dalam pembelajaran tematik terpadu yang dilakukan. Sedangkan untuk muatan lokal bahasa Inggris dijadikan mulok wajib yang diberikan sebanyak dua jam pelajaran setiap minggunya.

Sementara itu, untuk kegiatan ekstrakurikuler yang ditujukan dalam rangka pengembangan diri peserta didik, merupakan kegiatan yang tidak digolongkan pada mata pelajaran, tetapi merupakan kegiatan yang bertujuan untuk melayani peserta didik dalam mengaktualisasikan diri sesuai bakat dan minat masing-masing. Kepala sekolah beserta tim inti kurikulum dan para guru melakukan langkah-langkah sebagai berikut: i) review terhadap program ekstrakurikuler secara berkelanjutan yang selalu memperhatikan keinginan dan kehendak siswa dan orang tua siswa serta daya dukung yang ada (sekolah melakukan sosialisasi terhadap ekstrakurikuler yang ada dan diinginkan untuk kemudian 
diserahkan kepada siswa dan orang tua siswa ekstrakurikuler apa yang pilihan untuk diadakan); ii) berkoordinasi dengan guru yang diberikan tugas untuk berkoordinasi dengan pihak-pihak terkait dalam memfasilitasi kegiatan ekstrakurikuler yang dilakukan; iii) menyediakan sarana dan prasarana yang diperlukan, iv) mendatangkan instruktur tertentu yang tidak dimiliki sekolah.

Dalam pelaksanaan pembelajaran guru senantiasa melakukan pembelajaran dengan sistem siswa melakukan presentasi didepan kelas terhadap tugas yang diberikan, hal tersebut ditujukan untuk membangun rasa percaya diri dari setiap siswa. Selain itu juga pembelajaran dilakukan dengan berpusat pada siswa.

Keempat, pengembangan evaluasi hasil belajar, meliputi ketuntasan belajar, remedial/pengayaan, sistem penilaian, dan penetapan kelulusan.

Kelima, internalisasi nilai-nilai yang dapat membantu keberhasilan implementasi kurikulum SDN Ujung Menteng 01 Pagi, yaitu nilai religius, integritas, nasionalisme, gotong royong, mandiri dan sebagainya.

Selain itu implementasi kurikulum yang dilakukan, senantiasa memperhatikan berbagai faktor lainnya yang erat dan relevan untuk dijadikan bahan referensi dan pertimbangan. Di antaranya adalah: i) menginternalisasi dan mengimplementasikan delapan standar nasional pendidikan yang ada dalam perencanaan dan pelaksanaan kurikulum, ii) memastikan pelaksanaan kurikulum sesuai dengan kaidah Kurikulum 2013, iii) melakukan pengayaan dan pendalaman materi terhadap terhadap kelas IV, V dan khususnya kelas VI dalam menghadapi UASBN, iv) mengembangkan keterampilan berbasis IT sesuai dengan perkembangan yang ada.

Nilai lebih tersendiri yang dilakukan SDN Ujung Menteng 01 Pagi Jakarta adalah bahwa setiap aktifitas kegiatan dan pembelajaran yang ada di lingkungan sekolah memiliki Standar Operational Procedure (SOP). Sehingga tata kelola pelaksanaan dapat berjalan lebih tertib dan rapi serta berorientasi pada proses.

Secara khusus implementasi kurikulum berbasis pendidikan karakter dapat digambarkan sebagai berikut:

Pertama, religius. Implementasi nilai religius ini terinternalisasi dan terintegrasi pada pembelajaran Pendidikan Agama Islam. Selain itu juga di dukung melalui berbagai kegiatan pembiasaan yang dilakukan seperti seperti sholat zuhur berjamaah, tadarus bersama setiap hari yang dilakukan sebelum jam pelajaran dimulai, shodaqoh, tabungan kurban, serta adanya kegiatan ekstrakurikuler yang berbasis agama.

Sementara itu karena jumlah peserta didik yang beragama islam mencapai 99,3\%, maka jumlah peserta didik yang beragama non-muslim tidak sampai mencapai $1 \%$. Hal tersebut mengakibatkan pihak sekolah tidak dapat mengajukan untuk mendatangkan guru agama bagi yang nonmuslim karena jumlah yang tidak memenuhi persyaratan. Sehingga untuk pengembangan nilai religius bagi yang nonmuslim, SDN Ujung Menteng 01 Pagi Jakarta menjalin kerjasama dengan beberapa sekolah swasta yang berada di sekitar lingkungan sekolah dengan sangat baik. Sehingga kebutuhan akan pendidikan agama dan nilai religius yang ada dapat terpenuhi bagi seluruh peserta didik yang ada.

Kedua, integritas. SDN Ujung Menteng 01 Pagi senantiasa mengintegrasikan dan menginternalisasi nilai intergritas pada pandangan sikap dan prilaku dalam aktifitas pembelajaran dan kegiatan di sekolah. Salah satu contohnya adalah pembiasaan dalam aktivitas yang dilakukan siswa dalam melakukan transaksi di kantin sekolah. Dimana siswa melakukan transaksi sendiri baik membayar maupun mengambil uang kembalian. Petugas kantin hanya bertugas menyediakan makanan. Hal tersebut selain melatih kejujuran siswa juga menjaga kebersihan makanan yang disajikan di kantin.

Ketiga, nasionalisme. Nilai tersebut senantiasa diintegrasikan dalam aktifitas 
pembelajaran, dan pembiasaan yang dilakukan, seperti kegiatan upacara bendera, peringatan hari besar nasional, dan kegiatan pramuka. Serta didukung dengan media-media pembelajaran seperti banner, lukisan dan sebagainya yang berisi nilainilai wawasan kebangsaan seperti foto dan biografi pahlawan, budaya dan geografis nusantara serta lain sebagainya. Dimana hal-hal tersebut dapat ditemui hampir disetiap sudut sekolah.

Keempat, gotong royong. Nilai tersebut senantiasa diinternalisasi dan diintegrasikan dalam seluruh pembelajaran dan kegiatan. Strategi yang diaplikasikan adalah pembelajaran dengan kerja kelompok dan problem based learning. Selain itu pembiasaan yang dilakukan diantaranya adalah kerja bakti membersihkan kelas setiap hari, kegiatan Pemberantasan Sarang Nyamuk (PSN) setiap Jumat pagi, dan sebagainya.

Kelima, mandiri. Nilai ini terinternalisasi pada pembelajaran dan kegiatan pendidikan di SDN Ujung Menteng 01 Pagi Jakarta. Adapun materi dikembangkan dari seluruh materi pembelajaran (khususnya materi pembelajaran pendidikan jasmani dan olahraga). Selain itu juga didukung oleh kegiatan ekstrakurikuler pramuka yang menjadi ekskul wajib. Strategi pembelajaran kemandirian dengan diantaranya dengan menegakkan kedisiplinan, ketertiban dan kerapihan.

Untuk mendukung implementasi kurikulum yang ada, SDN Ujung Menteng 01 Pagi Jakarta memiliki beberapa program-program unggulan, diantaranya adalah: a) Sekolah Berbudaya Mutu; b) program Penguatan Pendidikan Karakter; c) Sekolah Ramah Anak; d) apel pagi yang dilakukan setiap hari sebelum aktifitas pembelajaran dimulai; e) tadarus dan kegiatan literasi membaca buku yang dilakukan setiap hari sebelum jam pembelajaran dimulai; f) pemberantasan sarang nyamuk yang dilakukan setiap hari Jumat; g) kegiatan berbagi dan sarapan bersama setiap hari Jumat; h) kerjasama dengan dinas terkait dalam hal budidaya perikanan yang terletak tidak jauh dari sekolah dan sebagainya.

\section{Manajemen Evaluasi/Pengendalian Kurikulum Berbasis Pendidikan Karakter SDN Ujung Menteng 01 Pagi Jakarta}

Evaluasi merupakan titik balik yang sangat penting dalam implementasi kurikulum. Evaluasi yang dilakukan sangat penting untuk memberikan masukan, dasar pertimbangan untuk melakukan pertimbangan dan kebijakan lebih lanjut.

Dalam evaluasi dan pengendalian pada lingkungan sekolah maka peran kepala sekolah, bukan hanya sebagai seorang pimpinan yang visioner, kecakapan kepala sekolah dalam mengatasi permasalahan dan kendala, serta mengendalikan sistem organisasi menjadi begitu krusial.

Kepala sekolah SDN Ujung Menteng 01 Pagi Jakarta, memiliki kemampuan yang sangat baik dalam manajerial yang ada. Implementasi kurikulum yang terjadi mulai dari perencanaan, pelaksanaan, hingga evaluasi dilakukan dengan sangat baik melalui, figur keteladan dan komunikasi yang efektif dengan seluruh elemen sekolah.

Dalam proses evaluasi kurikulum yang dilaksanakan, revisi ataupun pengembangan yang dilakukan didasarkan atas beberapa pertimbangan, diantaranya yaitu: 1) kurikulum pada SDN Ujung Menteng 01 Pagi Jakarta direvisi, apabila adanya kebijakan baru dari pemerintah pusat terhadap kurikulum yang berlaku secara nasional; 2) hasil rapat bersama seluruh warga sekolah baik guru, kepala sekolah dan juga komite sekolah apabila dalam dokumen perencanaan kurikulum yang berlaku saat itu, dirasakan perlu adanya perubahan atau pengembangan lebih lanjut; 3) visi, misi, dan tujuan yang dianggap sudah kurang relevan terhadap perkembangan masyarakat global yang terjadi.

Evaluasi kurikulum yang dilaksanakan, terdiri atas tiga fokus utama (Ahmadi, 2013), yaitu: 1) evaluasi terhadap dokumen 
kurikulum; 2) evaluasi terhadap implementasi kurikulum; dan 3) evaluasi terhadap hasil belajar. Tim inti perencana dan pengembangan kurikulum SDN Ujung Menteng 01 Pagi Jakarta yang dipimpin langsung oleh Kepala sekolah, melakukan revisi dan pengembangan, dalam rangka meningkatkan pelayanan terhadap kualitas pendidikan yang ada.

Pertama, evaluasi terhadap perencanaan kurikulum yang telah dituangkan dalam dokumen kurikulum. evaluasi terhadap dokumen kurikulum ini terdiri dari dua langkah utama, yaitu: 1) Evaluasi yang dilakukan terhadap dokumen kurikulum satuan pendidikan yang merupakan master plan SDN Ujung Menteng 01 Pagi Jakarta. Evaluasi yang dilakukan pada tahap ini dilakukan terhadap: i) visi, misi, dan tujuan sekolah yang menjadi arah pendidikan sekolah. Dengan arah pendidikan yang senantiasa di analisis, di evaluasi dan dikembangkan sesuai dengan perkembangan, diharapkan mampu mewujudkan citacita pendidikan yang ada; ii) evaluasi terhadap struktur kurikulum, hal ini menjadi perhatian agar senantiasa tidak keluar dari kaidah kurikulum nasional yang berlaku saat ini; iii) evaluasi terhadap isi kurikulum, dalam hal ini evaluasi yang dilakukan ditujukan untuk menganalisis dan mengembangkan kompetensi inti dan kompetensi dasar, materi dan pengalaman pembelajaran, serta pengembangan diri dan ekstrakurikuler yang disesuaikan dengan kebutuhan dan perkembangan; iv) evaluasi pembelajaran. Evaluasi ini dilakukan oleh kepala sekolah terhadap aktifitas pembelajaran guru dan siswa. Evaluasi ini untuk mengetahui bagaimana strategi, media, dan pendekatan pembelajaran yang dilakukan apakah sudah berjalan dengan efektif; v) evaluasi penilaian hasil belajar. Evaluasi ini terbagi atas dua hal yaitu evaluasi berbasis kelas melalui tes formatif, sumatif dan evaluasi sikap prilaku. Dan evaluasi berbasis sekolah yaitu terhadap nilai rapot, dan UASBN. Dalam evaluasi ini tentu saja ditetapkan kriteria terlebih dahulu baik untuk Kelulusan Mata Pelajaran, kenaikan kelas, serta kelulusan sekolah. 2) evaluasi juga dilakukan terhadap dokumen kurikulum yang ada di kelas. Dalam hal ini adalah evaluasi terhadap silabus, RPP, modul, serta media pembelajaran. Analisis dan pengembangan yang dilakukan agar panduan pelaksanaan pembelajaran di dalam kelas menjadi lebih handal dan relevan.

Kedua, evaluasi terhadap implementasi kurikulum. Evaluasi ini dilakukan terha-dap komponen kurikulum dan juga evaluasi terhadap sistem pendukung kurikulum. i) Evaluasi komponen kurikulum yang dilakukan oleh SDN Ujung Menteng 01 Pagi Jakarta adalah dengan kepala sekolah melakukan supervisi akademik ke dalam kelas saat pembelajaran berlangsung. Evaluasi yang dilakukan meliputi evaluasi terhadap perangkat pembelajaran (silabus dan RPP), pelaksanaan pembelajaran (strategi, materi, media dan evaluasi belajar berbasis kelas); ii) sementara evaluasi pendukung kurikulum yang dilakukan terdiri dari evaluasi terhadap guru, peserta didik, tenaga kependidikan, sarana prasarana, pembiayaan dan juga sistem administrasi yang ada di sekolah.

Ketiga, evaluasi terhadap penilaian hasil belajar. Evaluasi pada tahap ini menurut Ahmadi (2013) terdiri atas tiga macam, yaitu: 1) evaluasi terhadap hasil belajar; 2) evaluasi terhadap pelaksanaan ujian sekolah; dan 3) evaluasi terhadap tindak lanjut lulusan sekolah, untuk evaluasi ini memang belum dilakukan secara komprehensif. Tapi hanya melalui pengakuan tertulis dari sekolah menengah pertama terhadap peserta didik lulusan SDN Ujung Menteng 01 Pagi Jakarta, yang pada umumnya memiliki prestasi yang luar biasa khususnya dalam hal sikap dan prilaku yang ditunjukan.

Untuk mewujudkan implementasi kurikulum yang ajeg dan handal, pengendalian kurikulum senantiasa dilakukan khususnya oleh kepala sekolah dengan beberapa tahapan, yaitu: 1) komitmen, dalam hal ini seluruh warga sekolah khususnya guru dan tenaga kependidikan senantiasa diarahkan untuk menjadi figur 
teladan bagi peserta didik dengan memiliki disiplin yang tinggi dalam menjalankan tupoksinya, 2) komunikasi, hal ini menjadi sangat penting karena gagalnya suatu sistem sering diakibatkan adanya komunikasi yang tidak berjalan dengan efektif. Dalam membangun komunikasi yang efektif di antaranya dilakukan melalui membangun suasana kekeluargaan diantara warga sekolah, serta budaya value sharing, yaitu budaya saling berbagi pengetahuan dan wawasan yang dilakukan setiap Jumat siang selepas jam pelajaran.

\section{PENUTUP}

Manajemen kurikulum memegang peranan penting dalam terealisasinya visi, misi, dan tujuan sekolah yang telah dicanangkan. Bukan hanya dalam lingkup institusi pendidikan saja, tetapi juga pada cita-cita pendidikan nasional.

Keberhasilan atau kegagalan dalam implementasi kurikulum di sekolah sangat bergantung pada guru dan kepala sekolah. Karena dua figur tersebut merupakan kunci yang menentukan serta menggerakkan berbagai komponen dan dimensi yang ada di sekolah. Oleh karena itu, peningkatan kompetensi dan wawasan seiring dengan perkembangan sangat perlu dilakukan secara sistemik dan berkelanjutan.

Implementasi manajemen kurikulum yang ada di SDN Ujung Menteng 01 Pagi Jakarta, ditunjang oleh faktor kepala sekolah yang visioner dan komunikatif. Seperti diketahui salah satu faktor penunjang manajemen kurikulum tersebut adalah sikap dan gaya kepemimpinan kepala sekolah. Sebagai ujung tombak dalam manajemen kurikulum, kepala sekolah mengambil peran yang luar biasa sebagai inspirator, motivator, figur keteladanan, supervisi akademik, dan manajerial bagi segenap elemen yang ada di sekolah. Hal tersebut tentu saja menjadi kredit poin tersendiri bagi sekolah.

Selain untuk mengetahui bagaimana implementasi manajemen kurikulum berbasis pendidikan karakter yang ada di SDN Ujung Menteng 01 Pagi Jakarta sebagai good practice. Penelitian ini juga diharap- kan dapat memberi inspirasi dan kontribusi kepada seluruh insan yang berkecimpung di dunia pendidikan untuk mewujudkan pendidikan nasional yang tertuang dalam Undang Undang Nomor 20 Tahun 2003 yaitu berkembangnya potensi peserta didik agar menjadi manusia yang beriman dan bertaqwa kepada Tuhan Yang Maha Esa, berakhlak mulia, sehat, berilmu, cakap, kreatif, mandiri dan menjadi warga negara yang berdemokratis serta bertanggungjawab.

Hasil penelitian ini tidak dapat digeneralisir secara ekstrim, karena hasil penelitian kualitatif dengan metode studi kasus memiliki perbedaan pada masingmasing objek penelitian yang dipengaruhi oleh berbagai kondisi seperti perbedaan ruang, waktu dan juga pelaku.

\section{UCAPAN TERIMA KASIH}

Penulis menghaturkan terima kasih kepada Kepala Sekolah dan segenap guru SDN Ujung Menteng 01 Pagi Jakarta, yang dengan sangat ramah dan tangan terbuka memberikan kesempatan kepada Penulis untuk melakukan penelitian.

\section{DAFTAR PUSTAKA}

Ahmadi. (2013). Manajemen kurikulum : pendidikan kecakapan hidup. Yogyakarta: Pustaka Ifada.

Ali, M. (2014). Memahami riset perilaku dan sosial. Jakarta: Bumi Aksara.

Creswell. (2017). Research design: pendekatan metode kualitatif, kuantitatif, dan campuran. Yogyakarta: Pustaka Pelajar.

Defyanti, V. (2014). Pelaksanaan manajemen kurikulum 2013 pada tingkat sekolah dasar di kecamatan Tanjung Emas. Jurnal al-Fikrah, Vol. II, No. 2, Juli-Desember 2014 : 177-185.

Hamalik, O. (2010). Manajemen pengembangan kurikulum. Bandung: Rosdakarya.

Hasanah, U. (2016). Model-model pendidikan karakter di sekolah. Jurnal Pendidikan Islam, Vol. 7, 1834. 
Komisi Perlindungan Anak Indonesia. (2016, Juli 17). Dipetik Januari 30, 2018 , dari http://bankdata.kpai.go.id/tabulasidata/data-kasus-per-tahun/rinciandata-kasus-berdasarkan-klasterperlindungan-anak-2011-2016

Kosim, M. (2011). Urgensi pendidikan karakter. Jurnal Karsa, Vol. IXI, No. 1, 85-92.

LPMP DKI Jakarta. (2017). Panduan umum lomba budaya mutu sekolah dasar tahun 2017. Jakarta: Kementerian Pendidikan dan Kebudayaan.

Mentoring Agama Islam Weblog. (2014). Kenakalan remaja. Dipetik Januari 12, 2018, dari https://mentoringku.wordpress.com/ kenakalan-remaja/

Mulyasa, E. (2003). Kurikulum berbasis kompetensi (konsep, karakteristik, dan implementasi). Bandung: Rosda.

Mulyasa, E. (2013). Pengembangan dan implementasi kurikulum 2013. Bandung: Rosda.

Oliva, P., F. (1992). Developing the curriculum, 3rd Edition. New York: Harper Collins Publishers.

Rusman. (2011). Manajemen kurikulum. Jakarta: Rajawali Pers.

Sanjaya, W. (2008). Kurikulum dan pembelajaran: teori dan praktik pengembangan kuirkulum tingkat satuan pendidikan (KTSP). Jakarta: Kencana.

Tyler, R., W. (1949). Basic principles of curriculum and instruction. Chicago: The University of Chicago Press.

Undang Undang Nomor 20 Tahun 2003 tentang Sistem Pendidikan Nasional. (t.thn.).

Wahyudin, D. (2014). Manajemen kurikulum. Bandung: Rosda. 